\title{
Mapping of Student Sustainable Development Education Knowledge in Malaysia using Geographical Information System (GIS)
}

\author{
Hanifah Mahat ${ }^{1, *}$, Mohmadisa Hashim ${ }^{1}$, Nasir Nayan ${ }^{1}$, Yazid Saleh $^{1}$ \& Saiyidatina Balkhis Norkhaidi ${ }^{1}$ \\ ${ }^{1}$ Department of Geography and Environment, Faculty of Human Science, Universiti Pendidikan Sultan Idris, 35900 \\ Tanjong Malim, Perak, Malaysia \\ *Correspondence: Department of Geography and Environment, Faculty of Human Science, Universiti Pendidikan \\ Sultan Idris, 35900 Tanjong Malim, Perak, Malaysia. Tel: 60-5-450-5101. E-mail: hanifah.mahat@fsk.upsi.edu.my
}

Received: January 9, 2018

Accepted: January 21, $2018 \quad$ Online Published: January 29, 2018

doi:10.5430/wje.v8n1p27

URL: https://doi.org/10.5430/wje.v8n1p27

\begin{abstract}
This article aims to examine the levels of education for sustainable development (ESD) knowledge among students in secondary schools according to zones in Malaysia by using GIS mapping. The five main zones of the study were the north zone, the south zone, the east coast zone, the central zone, and the East Malaysia zone. This quantitative form of study used a questionnaire as research instrument. Two types of sampling techniques were applied, namely stratified sampling for school selection and simple random sampling for choosing respondents from the selected schools. The three ESD knowledge variables measured in this study were knowledge of ESD content, knowledge of environmental education and knowledge of health. The study results showed that in general the levels of sustainable development education knowledge of secondary school students in all zones were high for ESD content knowledge while moderate for environmental education knowledge and health knowledge. Meanwhile, the GIS map clearly indicates the levels of knowledge among students seemed high in the north zone, central zone and east Malaysia zone, at moderate levels in the south zone, and low in the east coast zone. In conclusion, there are differences between the zones in terms of levels of knowledge of sustainable development education, and this gives an indication that increasing sustainability-related activities in these zones with the participation of all parties-especially schools, local communities and non-governmental organisations - may disseminate sustainability knowledge and practices at all age levels and all school locations.
\end{abstract}

Keywords: education for sustainable development, ESD knowledge, GIS, secondary school students

\section{Introduction}

\subsection{Introduce the Problem}

The deterioration of environmental quality has caused concern to various parties. The interdependence between humans and the environment has led to the emergence of an awareness of the need to preserve and conserve the environment to for survival. The pollution that has already occurred has resulted in this dependency becoming more and more precarious and subsequently the aim of sustainable development has become paramount. Unplanned development has led to the environment experiencing degradation (Jamilah et al., 2011; John, 2007). In order to minimise the negative impacts of development on the environment, sustainable development practices are necessary to maintain environmental sustainability for present and future generations. According to the Brundtland Report (1987), sustainable development is defined as a process that aims to meet the current generation's needs without negatively impacting future generations' capabilities. This means that every thing or activity that we have today will also be owned and enjoyed by generations in the future. Moreover, in the Education for Sustainable Development Goals (SDGs) which were drafted at the end of the Sustainable Development Education Decade, a stated aim is that sustainability activities should be continued by future generations (United Nations, 2017). 


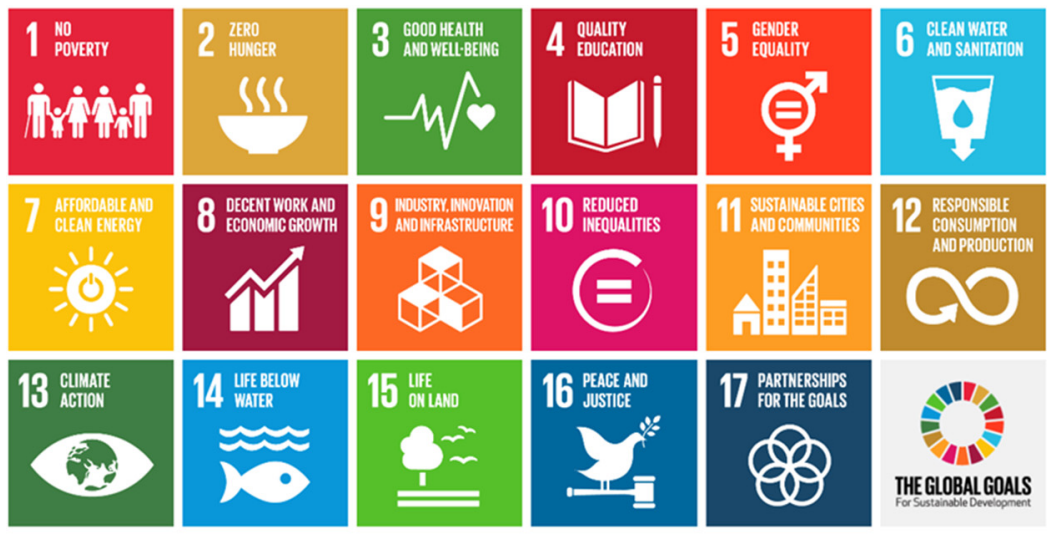

Figure 1. Seventeen (17) Sustainable Development Goals (SDGs)

Within these goals, seventeen aspects of sustainability are emphasised: elimination of poverty, elimination of hunger, health and wellbeing, quality education, gender equality, clean water and hygiene, clean and affordable energy, economic growth and good employment, innovative infrastructure and industry, inequality, sustainable cities and communities, sustainable consumption and production, sustainable production, climate change and disaster risk reduction, marine ecosystems, land ecosystems, peace and justice, and partnerships for development (Figure 1).

Awareness of the importance of sustainable development can be instilled through education. The right efforts among the community are needed in addition to providing awareness through education in order to ensure that the environment can be maintained for future generations (Hanifah, Yazid, Mohmadisa, \& Nasir, 2016). Education is a key factor in realising sustainable development and raising awareness of environmental issues (Robert et al, 2016). Education has the main role in enhancing the public's knowledge and awareness of environmental issues (Hanifah \& Mohamad Suhaily Yusri, 2016). The emphasis given to sustainable development is directed towards three main elements, namely the environment, society and the economy (Dernbach, 2003; Stoddart, 2011).

To achieve the goal of sustainable development, knowledge concerning it must be nurtured from early ages especially at the various school levels. According to Amer and Sara (2011), Kollmuss and Aggeyman (2002) and Linda and Charles (2009), greater knowledge in regard to the environment will lead to positive behavioural changes. The role of education as a catalyst for the success of sustainable development is clearly evidenced by the emphasis it is given in the National Environmental Policy as well as in the Third Malaysia Plan. The aim of the latter policy is to continue economic, social and cultural progress, and improve the quality of life of Malaysian people through fostering environmental wellbeing and sustainable development. Clearly, education and awareness are among the cornerstones of the Malaysia Green Strategy, which emphasises the importance of the concepts of environmental wellbeing and sustainable development in shaping attitudes of concern for the natural environment (Ministry of Science, Technology and Innovation, 2002).

The effort to applying environmental components to the education system has been formally implemented in Malaysia by the cabinet committee, which was established in 1974 to review the National Education policy with the aim of improving its implementation in order to create a united and disciplined society as well as to meet the need for trained manpower for the development of the country. The committee's report, published in 1979, decided on the implementation of Environmental Education across the curriculum in the Primary School Curriculum (KBSR) and the Integrated Secondary School Curriculum (KBSM). In 1993, KBSR introduced further environmental elements through the subject Man and Environment. The emphasis of environmental education was on spirituality, values and attitudes, as well as the relationship between humans and the environment. Some of the subjects involved were Islamic Education, Moral Education, Science and Local Studies.

Meanwhile, at the secondary school level environmental elements were focused on the Geography and Science subjects. Until the end of the 6th Malaysia Plan, the concept of environmental education in the national education system was still blurry. Environmental elements have been taught independently in a few particular subjects and have focused on increasing knowledge rather than inculcating pure values, or decision making and problem solving skills (Haryati, 2012). However, in 1989 the element of environmental education was included directly in the subjects of Geography and Science, and its inclusion in the subjects of Biology, Physics and Chemistry was coordinated through 
the Integrated Curriculum for Secondary Schools (KBSM). Environmental education elements are also taught in several other subjects in recognition of the cross-curriculum aspects of sustainability. The application of environmental education elements should be implemented by teachers in an effort towards sustainable development (Masitah, Azizi, Ahmad Makmom, Bahaman, \& Noriati, 2013). A teacher is an effective transformation agent to mobilise the concept of education for sustainable development by developing the knowledge and skills of future generations (Gough, 2005; Hanifah et al., 2017; Jinyu, 2009; Mohd Zohir \& Nordin, 2007).

Many parties believe that only through education can the thinking and actions of a person can be changed. Schools are the right institutions to educate future generations and shape their attitudes to include greater concern for the environment (Maria \& Hazinah, 2009; Noor Azizah \& Zanaton, 2015; Tiwi, 2006). Therefore, Education for Sustainable Development (ESD) is one of the practical ways to disseminate information at the school level in order to instil the seeds of environmental awareness so that today's generation may appreciate and value the environmental treasures being preserved for present and future generations (Hanifah, Mohamad Suhaily Yusri, \& Shahrudin, 2013). Therefore, a study of knowledge of sustainable development education is necessary to measure levels of student knowledge according to state zones, so as to assist the parties involved, enhancing their understanding as well as identifying the deficiencies that need to be addressed.

1.2 Differences in the Level of Knowledge of Sustainable Development Education among Students, based on Zones in Malaysia

Based on the definition of the concept of sustainable development education, or education for sustainable development, this study treats the ESD concept as an in-depth educational form of sustainable development. Its purposes were to create and cultivate awareness as well as to build continuous commitment towards the environment by taking into account economic, social and environmental elements of sustainability. This element of education refers to formal and informal activities performed either within the school area or outside the school surroundings. A study on the concept of sustainable development education by Masitah et al. (2011) involved 263 teachers and found that the level of knowledge and awareness of environmental issues among teachers was at a moderate level overall. This is in line with to the findings obtained in the study conducted by Hanifah et al. (2016) that teachers' limited knowledge of the content of sustainable development education shows that the concept of sustainable development has not been fully understood.

A previous zone-based study of the knowledge of sustainable development education found that students located in the rapidly developing urban areas of Selangor clearly showed a high level of understanding (Hanifah, Shaharuddin, Noraziah, \& Mohamad Suhaily Yusry, 2015). On the other hand, a study by Azizi et al. (2015) revealed that the level of knowledge, attitudes and awareness of students in the north zone of Malaysia was at a low level. The difference between these two findings may be due to geographical factors that influenced the availability of information among teachers and students. The influence of knowledge on environmentally-friendly behaviour is seen to be a dominant factor and needs to be studied. A study by Neeraj (2015) found that the level of environmental awareness among students in the rural areas was higher compared with the students living in urban areas, in line with the findings by Arba'at, Tajal and Suriati (2010). This was due to the fact that rural students' exposure to the environment was higher compared with students living in urban areas who are often exposed to the concrete jungle. However, Auwalu (2015) found that their location did not influence students' level of awareness towards the environment because urban and rural students actually have the same levels of perception towards the environment. Nurmaziah, Ahmad Hariza and Shamsul Azahari (2015) showed that respondents' behaviour was influenced by acceptance of zero waste practices, both during a purchase and during reuse activities. This situation clearly indicates that the respondents were aware of their responsibility for preserving the environment and not to degrade it even further. Factors contributing to this positive acceptance and knowledge may include workplace policies or awareness gained through programmes carried out by government and non-governmental organisations that worked together to create awareness regarding sustainable consumption practices.

Therefore, this study aimed to examine secondary school students' level of knowledge pertaining sustainable development education, according to state zones in Malaysia, by using GIS mapping. There were three main variables comprising levels of knowledge of sustainable development education: knowledge of ESD content, knowledge of environmental education and knowledge of health. The application of environmental awareness is very important as intrinsic value is the result of learning acquired in relation to life. The quality of the environment in the future will also improve as values cultivated through knowledge can influence decision makers in managing the environment and thus creating a more sustainable future. 


\section{Method}

This study involved 24 schools in Malaysia (Figure 2). The determination of states in Malaysia was based on zones in order to facilitate data collection and validity (Table 1). The stratified sampling method was used to obtain a study area classified according to five main zones, namely the north zone, the south zone, the east coast zone, the central zone and the East Malaysia zone. Each zone was to be represented by four schools while for the East Malaysia zone eight schools were involved, four from Sarawak and four from Sabah.

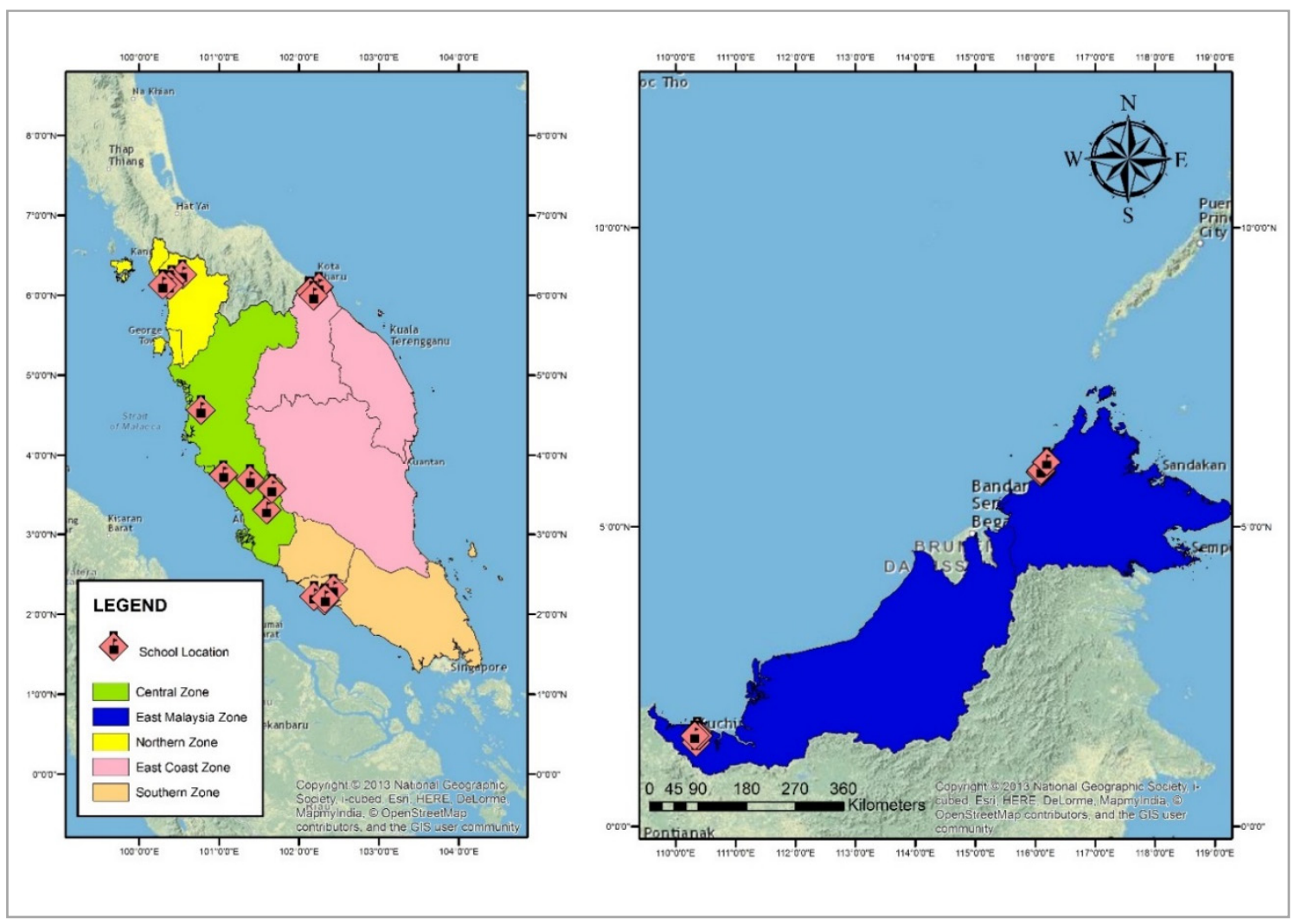

Figure 2. The Location of Schools in the Study

Table 1. The Number of Sample of School Respondents in Malaysia

\begin{tabular}{|c|c|c|}
\hline Zone & Number of School & Number of School Sample \\
\hline North & 4 school & 220 \\
\hline Central & 4 school & 205 \\
\hline South & 4 school & 122 \\
\hline East Coast & 4 school & 238 \\
\hline East Malaysia & $\begin{array}{c}8 \text { school } \\
\text { (4 Sarawak, } 4 \text { Sabah) }\end{array}$ & 295 \\
\hline Total & 24 & 1180 \\
\hline
\end{tabular}

\subsection{Study Instrument}

This study used a questionnaire form which was divided into two main sections: Parts A and B. Part A contained questions about students' backgrounds. Part B involved questions related to their knowledge of sustainable education, and covered the three sub variables: knowledge of ESD content, knowledge of environmental education and knowledge of health. The items were modified from studies by Suriati (2009) and Hanifah (2014); the reliability value was remeasured to ensure that the items used truly represent the study variables. 
Table 2 shows the reliability values of the sub variables of the study; all have a Cronbach's alpha in excess of 0.7 , an acceptable level (Juul, Van Rensburg, \& Steyn, 2012; Kline, 2000). The research instrument also underwent validity review by five academicians from Universiti Pendidikan Sultan Idris and Universiti Kebangsaan Malaysia with expertise in the educational content. For face validity, five Form 4 students were involved in testing the suitability and intelligibility of the questionnaire.

Table 2. The Reliability Value of Items in the Study

\begin{tabular}{lcc}
\hline \multicolumn{1}{c}{ Variables } & $\begin{array}{c}\text { Number of } \\
\text { Item }\end{array}$ & Alpha Cronbach Values \\
\hline ESD Content Knowledge & 12 & 0.626 \\
Environmental Education Knowledge & 8 & 0.843 \\
Health Knowledge & 10 & 0.831 \\
\hline
\end{tabular}

\section{Results and Discussion}

\subsection{The Background of the Respondents}

The respondents of the study consisted of 1180 Form 4 students. A total of 637 respondents (54\%) were from urban areas, and 543 respondents $(46 \%)$ were from rural areas. The results showed that there were 449 male students (38.1\%) and 731 female students (61.9\%). The frequency distribution in terms of respondents was 875 Malays (74.2\%), 81 Chinese (6.9\%), 28 Indians $28(2.4 \%)$ and 196 people of other ethnic groups including Sabah and Sarawak Bumiputeras (16.6\%).

Table 3. The Background of the Respondents

\begin{tabular}{llcc}
\hline The background of the respondents & $\mathbf{N}$ & $\mathbf{\%}$ \\
\hline School Location & Urban Areas & 637 & 54.0 \\
& Rural Areas & 543 & 46.0 \\
& Total & $\mathbf{1 1 8 0}$ & $\mathbf{1 0 0 . 0}$ \\
& Male & & \\
Gender & Female & 449 & 38.1 \\
& Total & 731 & 61.9 \\
& & 1180 & $\mathbf{1 0 0 . 0}$ \\
& Malays & & \\
Ethnic & Chinese & 875 & 74.2 \\
& Indians & 81 & 6.9 \\
& Sabah and Sarawak Bumiputeras & 28 & 2.4 \\
& Total & 196 & 16.6 \\
& & $\mathbf{1 1 8 0}$ & $\mathbf{1 0 0 . 0}$ \\
\hline
\end{tabular}

\subsection{Students' Level of Education for Sustainable Development Knowledge}

The analysis of the levels of sustainable development education knowledge involved descriptive analysis of mean, percentage, standard deviation and overall level. The levels were based on three cut-off points, namely low level (score 1.00-2.33) moderate level (score 2.34-3.66) and high level (score 3.67-5.00). The determination of these three levels was in line with Landell's (1997) recommendations.

As shown in Table 4, the level of respondents' knowledge of the content of sustainable development education was at low level in 23 students (1.9\%), a moderate level with 407 students (34.5\%) and high level with 750 students $(63.6 \%)$. It is clear that the sub variable of ESD content knowledge as a whole is at a moderate level (mean=2.62). The sub variable of knowledge of environmental education is at a low level in only 1 student $(0.1 \%)$, a moderate 
level with 363 students (30.8\%) and high level with 816 students (69.2\%). On average, the sub variable of environmental education knowledge (mean=2.69) is in the moderate score range. The health knowledge sub variable was at a low level in only 37 people (3.1\%), a moderate level in 461 people (39.1\%) and a high level in 682 people $(57.8 \%)$. On average, the health knowledge sub variable (mean=2.55) is at moderate level.

Table 4. The Level of Environmental Awareness, Measured through Student Knowledge

\begin{tabular}{lccccccccc}
\hline \multicolumn{1}{c}{ Variables } & \multicolumn{2}{c}{ Low level } & \multicolumn{2}{c}{ Medium level } & \multicolumn{2}{c}{ High level } & \multirow{2}{*}{ Mean } & SD & \multicolumn{2}{c}{ Mean } \\
& $\mathbf{N}$ & $\mathbf{\%}$ & $\mathbf{N}$ & $\mathbf{\%}$ & $\mathbf{N}$ & $\mathbf{\%}$ & & & level \\
\hline $\begin{array}{l}\text { ESD Content } \\
\text { Knowledge }\end{array}$ & 2 & 0.2 & 501 & 42.5 & 677 & 57.4 & 3.75 & 0.460 & High \\
$\begin{array}{l}\text { Environmental } \\
\begin{array}{l}\text { Education } \\
\text { Knowledge }\end{array}\end{array}$ & 1 & 0.1 & 363 & 30.8 & 816 & 69.2 & 2.69 & 0.464 & Medium \\
Health Knowledge & 37 & 3.1 & 461 & 39.1 & 682 & 57.8 & 2.55 & 0.557 & Medium \\
\hline
\end{tabular}

3.3 ANOVA test based on Difference of Student Awareness Level by Location

An ANOVA test is designed to evaluate the mean difference of quantitative dependent variables between three or more groups. In ANOVA analysis there should be a dependent variable and a free variable named a factor. Factors need to be in two or more stages (Norizan et al., 2010). For the purpose of rejection or acceptance of a hypothesis, the value of $\mathrm{F}$ is set at a level of $\mathrm{p}<0.05$. In this study, an ANOVA test was used to determine the effect of the differences between sub variables of education for sustainable development knowledge according to respondents' school zone, namely the North, Central, South, East Coast and East Malaysia zones.

As shown in in Table 5, using the one-way ANOVA test differences can be detected in the values of knowledge content of sustainable development education based on zones between the groups (mean=7.022), as well as variation in the groups (mean $=0.188$ ) which is $\mathrm{F}=37.340$ with $\mathrm{p}<0.05$. Regarding the sub variables of environmental education knowledge, there are also differences between the groups of zones (mean=4.916) and within the groups $(\mathrm{min}=0.340)$ which is $\mathrm{F}=14.464$ with $\mathrm{p}<0.05$. However, for the sub variable of health knowledge no clear differences between the zones were shown (mean=1.143), nor within the groups (mean=0.362) with value $\mathrm{F}=0.160$ and $\mathrm{p}>0.05$. This evidently shows that it is only the sub variables of content knowledge and environmental education knowledge that show differences according to the respondents' school zones.

Table 5. The Relation between the Variables of sustainable Development Education Knowledge and Zones

\begin{tabular}{llccccc}
\hline Variables & Source of Variation & JKD & df & MKD & F & $\boldsymbol{p}$ \\
\hline ESD Content & Between Group & 28.089 & 4 & 7.022 & 37.340 & .000 \\
Knowledge & Within Group & 220.975 & 1175 & .188 & & \\
& Total & 249.064 & 1179 & & & \\
\hline Environmental Education & Between Group & 19.663 & 4 & 4.916 & 14.464 & .000 \\
Knowledge & Within Group & 399.349 & 1175 & .340 & & \\
& Total & 419.012 & 1179 & & & \\
\hline \multirow{3}{*}{ Health Knowledge } & Between Group & 4.570 & 4 & 1.143 & 3.160 & .014 \\
& Within Group & 424.859 & 1175 & .362 & & \\
& Total & 429.430 & 1179 & & & \\
\hline
\end{tabular}

\subsection{GIS Mapping based on Difference of Student Awareness Level by Zone}

In Geographical Information Systems (GIS), surface representation is performed by storing the value of $\mathrm{x}, \mathrm{y}$ and $\mathrm{z}$ to determine the location of sample and the characteristics of the change represented by the value of $Z$. These points may be represented as contours where the same row of values may join to describe the surface as in the contour line 
or alternatively, they can be represented as a triangular irregular network (TIN) or as a grid surface. TIN is a vector data structure used to store and display surface models, whereas the grid is a spatial data structure that defines space as multiple cells of equal size arranged in rows and columns representing the surface. Various methods aim to represent a continuous surface through interpolation.

There are various interpolation techniques, but some commonly found in GIS are spline, inverse distance weighting (IDW), 'kriging', trend surface and polygon thiessen. In ArcGIS, some spatial interpolation techniques such as natural neighbours, spline with obstacles, topo to raster and trend are available. Spatial interpolation methods can generally be grouped into categories based on their basic hypothesis and mathematical properties such as geometric, statistical, geostatistical, simulated stochastic methods, simulated physical models and combined methods (Li et al., 2000). Finally, the rationale behind interpolation is to fill in detail invisible to the eye and expose a lot of smooth and subtle surfaces. Hence, distributable and sufficient number of data points in the area under investigation will reduce the uncertainty between the points.

By referring to Figure 3, it can be observed that the levels of students' knowledge are high (4.11-4.29) for the north and East Malaysia regions. For the east coast zone, the level of students' knowledge is at a low level (3.58), whereas in the south zone it seems to be moderate (3.58-411). This is in line with the findings of Hanifah, Shaharuddin, Noraziah, \& Mohamad Suhaily Yusry (2015) and Azizi et al. (2015), which showed that there were differences in the levels of knowledge of sustainable education between the states in Malaysia due to geographical factors that affected the availability of information among students.

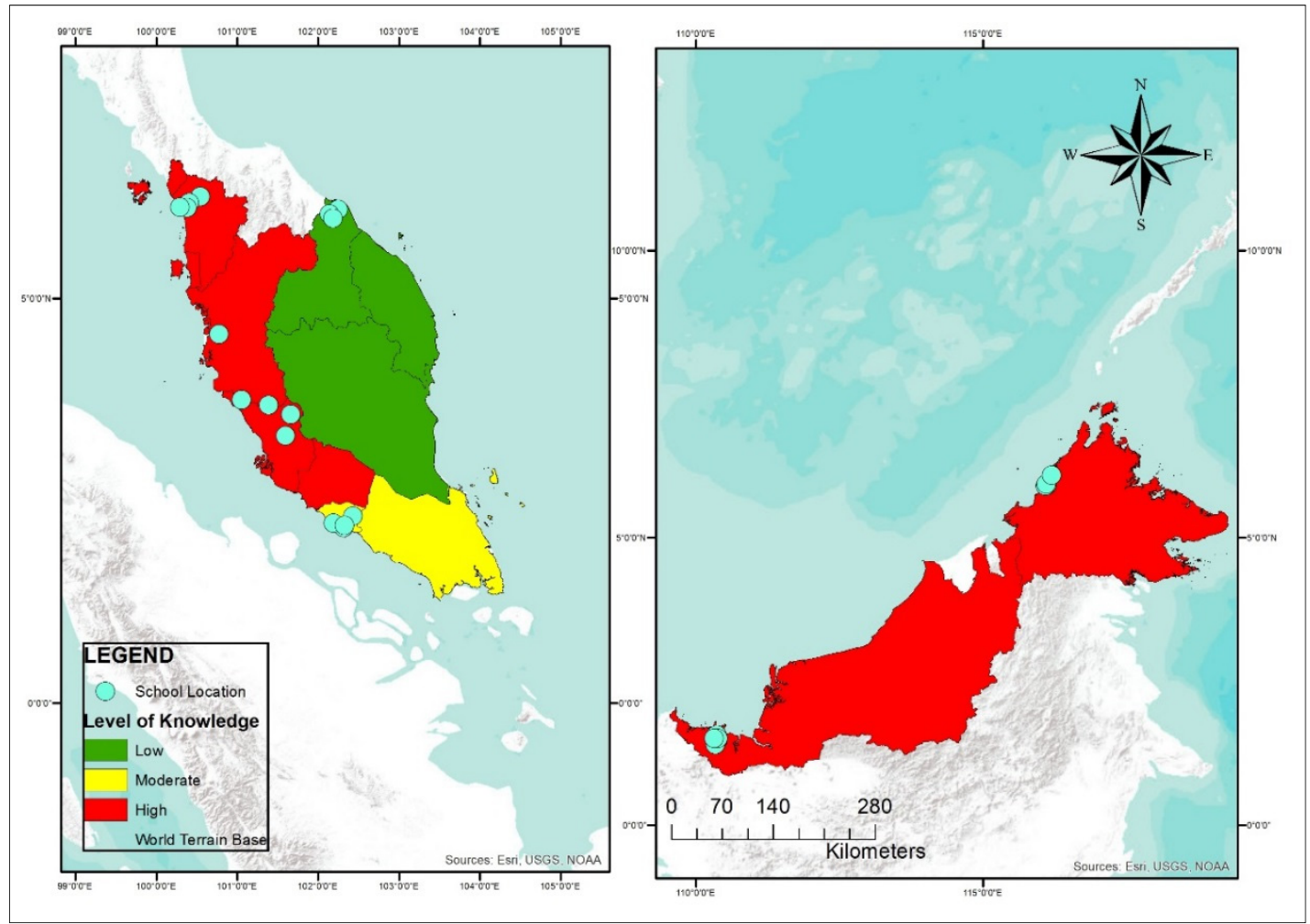

Figure 3. The Map of Level by Zone

\section{Discussion}

In conclusion, GIS map discussed earlier it is clearly seen that the levels of knowledge among students in the north, middle and East Malaysia zones demonstrate significantly higher levels than the other zones. They are followed by the south zone, at a moderate level, and then the east coast zone, which shows the lowest level of knowledge. Through these findings it is clear that there are differences between zones in the level of knowledge of sustainable development education, and this provides a sign and indicates that action to be taken to increase sustainability activities in the zones with lower levels. Regardless of location and zone, students should be provided with information and be able to implement sustainability practices continuously. The differences between zones are also related to various factors which need to be investigated, including the roles of the school administrators, teachers, 
community or government agencies that should expose students to this knowledge. Therefore, schools are the best institutions to apply the basic principles of sustainable development. Students are seen as an important asset to maintain sustainability into the future. The application of sustainability knowledge should be inculcated early to create the awareness which leads to the development of pro-environmental behaviour.

\section{Acknowledgements}

This study was conducted with the help of the Fundamental Research Grant Scheme (FRGS 2015-0162-106-02). Thanks are due to the Ministry of Higher Education Malaysia, which has provided this research funding, and to the management, teachers and secondary school students involved in this study

\section{References}

Aaron, M. M. (2010). The effects of gender on climate change knowledge and concern in the American public. Popular and Environment, 30(1), 66-87.

Aisyah, N., \& Zainora, M. (2012). The level of awareness towards environmental issues and concern among students in tertiary level: Case study of universities students in Kuala Lumpur and Klang Valley of Malaysia. 11th International Congress of Asian Planning Schools Association (APSA 2011), 19-21 September 2011, University of Tokyo Hongo Campus, Tokyo, Japan.

Amer, M., \& Sara, K. (2011). A survey of relationship between the environmental attitudes and environmental knowledge and energy consumption behavior among citizens of Urmia, West Azerbaijan, Iran. International Journal of Social Sciences and Humanities, 1, 27-37.

Arba'at, H., Tajal, A. N., \& Suriati, S. (2010). The status on the level of environmental awareness in the concept of sustainable development amongst secondary school students. In Procedia Social and Behavioral Sciences (pp. 1276-1280).

Arbaat, H., \& Norshariani, Abd Rahman Sharifah Intan Sharina, S. A. (2013). The level of environmental knowledge, awareness, attitudes and practices among UKM students. Procedia Social and Behavioral Sciences, 18, 643-648.

Asmawati, D., Nor Ba'yah, A. K., \& Fatimah, Y. (2011). A study on the knowledge, attitudes, awareness status and behaviour concerning solid waste management. Procedia Social and Behavioral Sciences, 18, 643-648. https://doi.org/10.1016/j.sbspro.2011.05.095

Auwalu, R. A. (2015). Influence of school location on environmental awareness level among secondary school students in Terengganu, Malaysia. OSR Journal of Environmental Science, Toxicology and Food Technology, 9(3), 54-61.

Azizi, M., Masitah, M. Y., Nazifah, S. I., Khaidir, A., \& Noriati, A. R. (2015). Hubungan antara tahap pengetahuan, sikap, kesedaran dengan kepemimpinan instruksional pendidikan alam sekitar dalam kalangan pengetua di negeri Kedah dan Pulau Pinang. Seminar Kebangsaan Majlis Dekan. (In Malay)

Dernbach, J. C. (2003). Achieving sustainable development: The Centrality and multiple facets of integrated decisionmaking. Indiana Journal of Global Legal Studies, 10(1), 247-285. https://doi.org/10.2979/gls.2003.10.1.247

Gough, A. (2005). Education for sustainable development: challenges for schools, curriculum and instruction. Seminar Pendidikan JPPG, 28-30 Ogos, Hotel Shangri-La, Penang.

Hanifah, M. (2014). Kesedaran dan komitmen pendidikan pembangunan lestari dalam komuniti sekolah menerusi program sekolah lestari di Malaysia. (PhD Thesis). Universiti Pendidikan Sultan Idris. (In Malay)

Hanifah, M., \& Mohamad Suhaily Yusry, C. N. (2015). 3r practices among preschool pupils through the environmental education curriculum. The Fourth International Conference on Advancement of Development Administration 2015-Social Sciences and Interdisciplinary Studies (The 4th ICADA 2015--SSIS) Conference 28th to 30th May 2015, Bangkok, Thailand. (pp. 1-12).

Hanifah, M., Mohamad Suhaily Yusri, C. N., \& Nurul Izza, A. (2015). Kajian tahap amalan kelestarian dalam kalangan murid prasekolah Kementerian Pendidikan Malaysia daerah Hulu Langat, Selangor. International Conference of Human Science. Tanjung Malim: Fakulti Sains Kemanusiaan, Universiti Pendidikan Sultan Idris. (In Malay) 
Hanifah, M., Mohamad Suhaily Yusri, C. N., \& Shahrudin, I. (2013). Kesedaran pendidikan pembangunan lestari menerusi program sekolah lestari dalam kalangan pelajar sekolah di Malaysia. Jurnal Geografi, 1(2), 44-58. (In Malay)

Hanifah, M., Shaharuddin, A., Mohamad Suhaily Yusri, C. N., \& Noraziah, A. (2014). Pendidikan Pembangunan Lestari - Hubungan kesedaran antara ibu bapa dengan pelajar. Malaysian Journal of Society and Space, 10(5), 71-84. (In Malay)

Hanifah, M., Shaharuddin, A., Noraziah, A., \& Mohamad Suhaily Yusry, C. N. (2015). Tahap penggunaan lestari dalam kalangan guru di Puchong, Selangor. Sains Humanika, 5(1), 19-26. (In Malay)

Hanifah, M., Yazid, S., Mohmadisa, H., \& Nasir, N. (2016). Model Development on Awareness of Education for Sustainable Schools Development in Malaysia. Indonesian Journal of Geography, 48(1), 39-48.

Haryati, S. (2012). Pendidikan alam sekitar menyumbang kepada peningkatan kualiti hidup masyarakat Malaysia. (PhD Thesis).Universiti Tun Hussein Onn Malaysia. (In Malay)

Jamilah, A., Hasrina, M., Hamidah, A. H., \& Juliana, A. W. (2011). Pengetahuan, sikap dan amalan masyarakat Malaysia terhadap isu alam sekitar. Akademika, 81(3), 103-115. (In Malay)

Jamilah, A., Shuhaida, M. N., \& Nurzali, I. (2015). Investigating students' environmental knowledge, attitude, practice and communication. Asian Social Science, 11(16), 284-293.

Jinyu, L. (2009). Education for sustainable development in teacher education: Issues in the case of York University in Canada. Asian Social Science, 5(5), 46-49.

John, H. (2007). Human population as a dynamic factor in environmental degradation. Journal Popul Environ, 28(1), 223-236.

Juul, L., Van Rensburg, J. A., \& Steyn, P. (2012). Validation of the king's health questionnaire for South Africa in English, Afrikaans and Xhosa. South African Journal of Obstetrics and Gynaecology, 18(3), 82-84. https://doi.org/10.7196/sajog.498

Kline, P. (2000). The handbook of psychological testing ( $\left.{ }^{\text {nd }} \mathrm{Ed}\right)$. London: Routledge.

Kollmuss, A., \& Aggeyman, J. (2002). Mind the gap: Why do people act environmentally and what the barriers to pro-environmental behaviour? Environmental Educational Research, 8(3), 240-260. https://doi.org/10.1080/13504620220145401

Landell, K. (1997). Management by menu. London: Wiley and Sons Inc.

Linda, S., \& Charles, V. (2009). Encouraging pro-environmental behaviour: An integrative review and research agenda. Journal of Environmental Pchycology, 29, 309-317.

Maria, S., \& Hazinah, N. H. (2009). Penerapan pendidikan alam sekitar merentas kurikulum di kalangan guru sekolah menengah: Satu tinjauan. (Laporan Geran FRGS). Universiti Pendidikan Sultan Idris. (In Malay)

Masitah, M. Y., Azizi, M., Ahmad Makmom, A., Bahaman, A. S., \& Noriati, A. R. (2013). Faktor-faktor yang mempengaruhi efikasi kendiri guru sekolah menengah di Malaysia dalam pelaksanaan pendidikan alam sekitar. Asia Pacific Journal of Educators and Education, 28(1), 131-153. (In Malay)

Ministry of Science, Technology and Innovation. (2002). Dasar Alam Sekitar Negara. Kementarian Sains Teknologi dan Alam Sekitar.

Neeraj, K. S. (2015). A Study on environmental awareness of college students in relation to sex, rural- urban background and academic streams wise. Journal of New Horizons in Education, 4(2), 1-19.

Nor Azizah, S., \& Zanaton, H. I. (2015). Kesedaran alam sekitar melalui aplikasi kendiri alam sekitar (KAKAS). Jurnal Personalia Pelajar, 18(2), 31-44. (In Malay)

Nurmaziah, Z., Ahmad Hariza, H., \& Shamsul Azahari, Z. B. (2015). Penerimaan dan tingkah laku pengguna terhadap amalan sisa sifar ke arah penggunaan lestari. 19th MACFEA National Seminar 2015 (pp 274-279). (In Malay)

Robert, Laurie Yuko, Nonoyama, T., Rosalyn, M., \& Charles, H. (2016). Contributions of education for sustainable development (ESD) to quality education: A Synthesis of research. Journal Research, 10(2), 1-9.

Stoddart, H. (2011). A Pocket guide to sustainable development governance. Retrieved from http://www.stakeholderforum.org/fileadmin/files/sdgpocketguideFINAL- no\%20crop\%20marks.pdf 
Suriati, S. (2009). Tahap kesedaran alam sekitar dalam konsep pembangunan lestari dalam kalangan pelajar sekolah menengah. (Tesis Sarjana). Universiti Kebangsaan Malaysia. (In Malay)

Tiwi, K. (2006). Perkaitan antara pengetahuan dan sikap terhadap alam sekitar di kalangan guru pelatih Maktab Perguruan Batu Lintang. Jurnal Penyelidikan IPBL, 7, 61-77. (In Malay)

United Nations. (2017). Education for sustainable development goals. France. Retrieved from http://unesdoc.unesco.org/images/0024/002474/247444e.pdf 